\title{
Heat stroke
}

\author{
Toru Hifumi ${ }^{1,5^{*}}$, Yutaka Kondo ${ }^{2}$, Keiki Shimizu ${ }^{3}$ and Yasufumi Miyake ${ }^{4}$
}

\begin{abstract}
Background: Heat stroke is a life-threatening injury requiring neurocritical care; however, heat stroke has not been completely examined due to several possible reasons, such as no universally accepted definition or classification, and the occurrence of heat wave victims every few years. Thus, in this review, we elucidate the definition/ classification, pathophysiology, and prognostic factors related to heat stroke and also summarize the results of current studies regarding the management of heat stroke, including the use of intravascular balloon catheter system, blood purification therapy, continuous electroencephalogram monitoring, and anticoagulation therapy.

Main body: Two systems for the definition/classification of heat stroke are available, namely Bouchama's definition and the Japanese Association for Acute Medicine criteria. According to the detailed analysis of risk factors, prevention strategies for heat stroke, such as air conditioner use, are important. Moreover, hematological, cardiovascular, neurological, and renal dysfunctions on admission are associated with high mortality, which thus represent the potential targets for intensive and specific therapies for patients with heat stroke. No prospective, comparable study has confirmed the efficacy of intravascular cooling devices, anticoagulation, or blood purification in heat stroke.

Conclusion: The effectiveness of cooling devices, drugs, and therapies in heat stroke remains inconclusive. Further large studies are required to continue to evaluate these treatment strategies.

Keywords: Heat stroke, Blood purification therapy, Anticoagulation, JAAM criteria, Core body temperature, Intravascular cooling
\end{abstract}

\section{Background}

Heat stroke is a life-threatening injury requiring neurocritical care, and there have been at least 3332 deaths attributed to heat stroke from 2006 to 2010 in the USA [1]. Regarding heat stroke, 28-day and 2-year mortality rates have been reported to be 58 and $71 \%$, respectively [2]. In addition, the number of deaths from heat stroke has been reported to increase due to climate change [1]. By the 2050s, heat stroke-related deaths are expected to rise by nearly 2.5 times the current annual baseline of approximately 2000 deaths [2].

Unfortunately, heat stroke has not been comprehensively examined due to several possible reasons. First, while sepsis, acute respiratory distress syndrome (ARDS), and acute kidney injury (AKI) include simple and commonly used definitions, no universally accepted definition

\footnotetext{
* Correspondence: hifumitoru@gmail.com

${ }^{1}$ Emergency Medical Center, Kagawa University Hospital, 1750-1 Ikenobe, Miki, Kita, Kagawa 761-0793, Japan

${ }^{5}$ Department of Emergency and Critical Care Medicine, St. Luke's

International Hospital, 9-1 Akashi-cho, Chuo-ku, Tokyo 104-8560, Japan

Full list of author information is available at the end of the article
}

of heat stroke exist in the clinical settings. Second, because a large number of heat stroke victims are uncommon in the USA or European countries (ex. 1995, and 1999 in Chicago, 2003 in Paris) [2-5], clinical research has not been continuously conducted in these regions.

Several review articles regarding heat stroke focusing on critical care have been published in the early 2000s [6, 7]; moreover, additional new devise for cooling, blood purification therapy for renal/hepatic failure, continuous electroencephalogram (cEEG) monitoring, and the use of drugs, such as anticoagulants, for treating heat stroke have become readily available, and substantive clinical research regarding such devises/drugs has been published in the 2010s [8-13].

Thus, in the current review, we elucidate the definition/classification, pathophysiology, and prognostic factors associated with heat stroke and also summarize the results of current studies regarding the management of heat stroke, including the use of intravascular balloon catheter systems, blood purification therapy, cEEG monitoring, and anticoagulants. 


\section{Review}

\section{Definition and classification of heat stroke}

Historically, heat stroke has been classified into two groups according to the presence or absence of exertion. Exertional heat stroke develops in able-bodied individuals, such as athletes, soldiers, or laborers, and performing rigorous physical activities [1]. In contrast, nonexertional heat stroke can develop during low-level physical activities among elderly, ambulatory individuals with comorbidities including obesity, diabetes, hypertension, heart disease, renal disease, dementia, and alcoholism [1].

To date, no universally accepted definition of heat stroke exists. The most commonly used definition of heat stroke worldwide is the Bouchama's definition [6]. Bouchama has defined heat stroke as a core body temperature that rises above $40{ }^{\circ} \mathrm{C}$, accompanied by hot dry skin and central nervous system abnormalities, such as delirium, convulsions, or coma. Heat stroke results from exposure to a high environmental temperature or from strenuous exercise [6]. Bouchama has also proposed an alternative definition of heat stroke on the basis of its pathophysiology, stating that heat stroke is a form of hyperthermia associated with a systemic inflammatory response that leads to a syndrome of multiorgan dysfunction, predominantly encephalopathy [6].

Pease et al. have reported an unusual heat wave that lasted 9 days in France in 2003 [14] and referred to the following criteria according to the Bouchama's definition: the alteration of mental status (coma, delirium, disorientation, or seizures); a body core temperature of $>40.6{ }^{\circ} \mathrm{C}$ or a documented evidence of cooling before the first record temperature; a reliable history of compatible environmental exposure; and the presence of hot, dry, or flushed skin. In another study, Misset et al. defined heat stroke as "the presence of hyperthermia of $>40.5^{\circ} \mathrm{C}$ " [15], but the phrase "core body temperature" was not included in their definition. Consequently, specific body temperature and the use of phrase "core body temperature" vary across studies.

In Japan, the Japanese Association for Acute Medicine (JAAM) has collected data through a nationwide heat-related illness registry of patients diagnosed as having heat-related illnesses (including heat stroke) regardless of the core body temperature since 2006 [16, 17]. The JAAM has established and published the criteria for heat-related illnesses, including heat stroke, in 2014 [18] (Fig. 1).

\begin{tabular}{|c|c|c|c|c|c|}
\hline \multicolumn{6}{|c|}{$\begin{array}{l}\text { Classification recommended by the Japanese Association of Acute Medicine "Committee related to heatstroke" } \\
\text { Japanese Association of Acute Medicine Heat Related Illness Classification } 2015\end{array}$} \\
\hline & Symptoms & Severity & Treatment & $\begin{array}{l}\text { Classification } \\
\text { from clinical } \\
\text { presentations }\end{array}$ & $\begin{array}{l}\text { First aid can be conducted and } \\
\text { patient is monitored only when } \\
\text { Stage I symptoms gradually } \\
\text { improve }\end{array}$ \\
\hline $\begin{array}{l}\text { Stage I } \\
\text { (First aid and } \\
\text { observation) }\end{array}$ & $\begin{array}{l}\text { Dizziness, faintness, slight yawning } \\
\text { Heavy sweating } \\
\text { Muscle pain, stiff muscles (muscle } \\
\text { cramps) } \\
\text { Impaired consciousness is not } \\
\text { observed (JCS =0) }\end{array}$ & & $\begin{array}{l}\text { May be handled on site } \\
\text { under normal conditions } \\
\rightarrow \text { Resting in a cool place, } \\
\text { cooling the body surface, } \\
\text { and orally supplying water } \\
\text { and } \mathrm{Na}^{+}\end{array}$ & \multirow{2}{*}{$\begin{array}{l}\text { Heat cramp } \\
\text { Heat syncope } \\
\text { Heat exhaustion }\end{array}$} & \multirow{2}{*}{$\begin{array}{l}\text { The patient should immediately } \\
\text { be taken to the hospital in the } \\
\text { event when stage II symptoms } \\
\text { occur or improvement in Stage I } \\
\text { is not observed } \\
\text { (assessed by others) }\end{array}$} \\
\hline $\begin{array}{c}\text { Stage II } \\
\text { (Should be taken } \\
\text { to a medical } \\
\text { institution) }\end{array}$ & $\begin{array}{l}\text { Headache, vomiting, } \\
\text { fatigue, sinking feeling, and } \\
\text { declined concentration and } \\
\text { judgement }(\mathrm{JCS} \leq 1)\end{array}$ & & $\begin{array}{l}\text { Examination at a medical } \\
\text { institution is necessary } \\
\rightarrow \text { Body temperature } \\
\text { management, resting, and } \\
\text { sufficiently supplying } \\
\text { water and } \mathrm{Na}^{+} \text {(by drip } \\
\text { infusion if oral intake is } \\
\text { difficult) }\end{array}$ & & \\
\hline $\begin{array}{c}\text { Stage III } \\
\text { (Inpatient hospital } \\
\text { care) }\end{array}$ & $\begin{array}{l}\text { Includes at least one of the following: } \\
\text { (C) central nervous system } \\
\text { manifestation (impaired } \\
\text { consciousness JCS } \geq 2 \text {, cerebellar } \\
\text { symptoms, convulsive seizures) } \\
\text { (H/K) hepatic/renal dysfunction } \\
\text { (follow-up following admission to } \\
\text { hospital, hepatic or renal impairment } \\
\text { requiring inpatient hospital care) } \\
\text { (D) Coagulation disorder (diagnosed } \\
\text { as DIC according to acute phase DIC } \\
\text { diagnostic criteria (Japanese } \\
\text { Association of Acute Medicine) } \\
\rightarrow \text { Most severe of the three types }\end{array}$ & & $\begin{array}{l}\text { Inpatient hospital care } \\
\text { (depending on the case, } \\
\text { intensive care) is necessary } \\
\rightarrow \text { Body temperature } \\
\text { management } \\
\text { (internal body cooling, } \\
\text { intravascular cooling, etc. } \\
\text { are carried out along with } \\
\text { body surface cooling) } \\
\text { Respiratory and circulatory } \\
\text { care } \\
\text { DIC treatment }\end{array}$ & Heat stroke & $\begin{array}{l}\text { Whether or not it is Stage III is } \\
\text { determined by ambulance staff } \\
\text { or at examination/checkup after } \\
\text { arrival at hospital }\end{array}$ \\
\hline
\end{tabular}

Fig. 1 Japanese Association of Acute Medicine Heat-Related IIIness criteria. DIC, disseminated intravascular coagulation; JCS, Japan Coma Scale 
Heat stroke was defined as patients exposed to high environmental temperature who met one or more of the following criteria:

I. Central nervous system manifestation (impaired consciousness with a Japan Coma Scale score of $\geq 2$ [19], cerebellar symptoms, convulsions, or seizures);

II. Hepatic/renal dysfunction (follow-up following admission to hospital, hepatic or renal impairment requiring inpatient hospital care);

III. Coagulation disorder [diagnosed as disseminated intravascular coagulation (DIC) by the JAAM] [20, 21].

Apparently, the body temperature was not included in these diagnostic criteria because of several fatal cases of patients whose body temperatures were below $40{ }^{\circ} \mathrm{C}$ that were observed in clinical practice [22].

In 2016, the JAAM Heat Stroke (JAAM-HS) Committee launched a working group (JAAM-HS-WG) to analyze the collected megadata regarding heat-related illnesses. The JAAM-HS-WG further simplified the heat stroke classification [22]. The modified JAAM heat stroke definition included patients exposed to high environmental temperature and meeting at least one of the following criteria:

I. Glasgow Coma Scale (GCS) score of $\leq 14$,

II. Creatinine or total bilirubin levels of $\geq 1.2 \mathrm{mg} / \mathrm{dL}$,

III. JAAM DIC score of $\geq 4$.

The difference between the definitions/classifications of heat stroke among Bouchama's definition and the JAAM and JAAM-HS-WG criteria is summarized in Table 1.

\section{Pathogenesis}

\section{Thermoregulation}

A normal body temperature is maintained at approximately $37{ }^{\circ} \mathrm{C}$ by the anterior hypothalamus through the process of thermoregulation [23, 24]. Several mechanisms related to sweating, such as vaporization, radiation, convection, and conduction, function to cool the body surface [25]. As the body temperature increases, active sympathetic cutaneous vasodilation increases blood flow in the skin and initiates thermal sweating [26, 27]. Cutaneous vasodilation causes a relative reduction in intravascular volume, leading to heat syncope [28]. The loss of salts and water through sweat induces dehydration and salt depletion, which are associated with heat exhaustion and cramps unless appropriate supplementations of water and salt are initiated [28]. Further loss of salt and water impairs thermoregulation followed by the reduction of visceral perfusion due to shunt from the central circulation to the skin and muscles, resulting in organ failure $[6,28,29]$. Therefore, heat stroke is a condition of multiple organ failure caused by hot environment.

\section{Heat shock response}

Heat shock proteins (HSP) are a family of proteins produced by nearly all cells in response to stressful conditions, including heat shock as well as other stresses, such as exposure to cold and ultraviolet light $[6,30]$. Increased levels of HSPs, such as HSP70, are necessary for acquired heat tolerance. Moreover, the overexpression of HSP70 in response to heat stress can protect against organ dysfunction and reduces mortality in rats [30].

Table 1 Comparison of Bouchama's definition and the JAAM criteria for heat stroke

\begin{tabular}{|c|c|c|c|c|}
\hline & & Bouchama's definition & JAAM criteria & JAAM-HS-WG criteria \\
\hline \multicolumn{2}{|c|}{ Environment } & $\begin{array}{l}\text { Exposure to } \\
\text { environmental } \\
\text { heat (classic heat stroke) }\end{array}$ & \multicolumn{2}{|c|}{$\begin{array}{l}\text { Exposure to high } \\
\text { environmental } \\
\text { temperature }\end{array}$} \\
\hline Body temperature & & $\begin{array}{l}\text { Core body } \\
\text { temperature }>40^{\circ} \mathrm{C}\end{array}$ & - & - \\
\hline \multirow[t]{6}{*}{ Organ dysfunction } & Central nervous system & $\begin{array}{l}\text { Delirium, convulsions, } \\
\text { or coma }\end{array}$ & $\begin{array}{l}\text { Impaired consciousness JCS } \geq 2 \text {, } \\
\text { cerebellar symptoms, } \\
\text { convulsive seizures }\end{array}$ & GCS score $\leq 14$ \\
\hline & Coagulation & - & Diagnosed as DIC by JAAM & JAAM DIC score $\geq 4$ \\
\hline & Liver & - & \multirow{2}{*}{$\begin{array}{l}\text { Follow-up after admission } \\
\text { to hospital, hepatic or renal } \\
\text { impairments requiring } \\
\text { inpatient hospital care }\end{array}$} & \multirow{2}{*}{$\begin{array}{l}\text { Creatinine or total } \\
\text { bilirubin levels } \geq 1.2 \mathrm{mg} / \mathrm{dL}\end{array}$} \\
\hline & Renal & - & & \\
\hline & Cardiovascular & - & - & - \\
\hline & Respiratory & - & - & - \\
\hline
\end{tabular}




\section{Pathophysiology}

Hyperthermia due to passive heat exposure facilitates the leakage of endotoxin from the intestinal mucosa to the systemic circulation as well as the movement of interleukin (IL)-1 or IL-6 proteins from the muscles to the systemic circulation [31]. This causes an excess activation of leukocytes and endothelial cells manifested by the release of various cytokines and high-mobility group box 1 protein (HMGB1), which is a prototypic alarmin (endogenous molecules that signal tissue and cellular damage). Together, these processes cause the systemic inflammatory response syndrome $[6,32,33]$.

The inflammatory and coagulation responses to heat stroke, together with direct cytotoxic effects of heat, injure the vascular endothelium, causing microthromboses [6]. Platelet counts decrease because of microthrombosis, the secondary consumption of platelets, and hyperthermia-induced platelet aggregation. Heat stroke also suppresses platelet release from bone marrow due to megakaryocyte susceptibility to high temperature exposures. Heat stroke-induced coagulation activation and fibrin formation clinically manifest DIC.

\section{Prognostic factors}

As mentioned above, because the definition of heat stroke varies across studies, detailed examinations, rather than mere results, are required to understand these study findings (Table 2).
Patients exposed to the August 2003 heat wave in Paris were examined to identify the prognostic factors, and several studies examining different populations have been published. Hausfater et al. have examined all patients who developed the core temperatures of $>38.5{ }^{\circ} \mathrm{C}$, who were admitted to one of the emergency departments during the August 2003 heat wave in Paris. Previous treatment with diuretics, living in an institution, age $>80$ years, the presence of cardiac disease or cancer, core temperature $>40{ }^{\circ} \mathrm{C}$, systolic arterial pressure < $100 \mathrm{mmHg}$, GSC scale $<12$, and transportation to hospital in ambulance were identified as prognostic factors associated with death for nonexertional heatstroke [34]. Argaud et al. examined long-term outcome in 83 patients with nonexertional heatstroke resulting from the August 2003 heat wave in Paris and having core temperatures $>40{ }^{\circ} \mathrm{C}$. Multivariate cox proportional hazard model analysis revealed an independent contribution to 2 -year mortality if patients were staying at an institution (hazard ratio (HR), 1.98; 95\% confidence interval (CI), 1.05-3.71), if they used long-term antihypertensive medications (HR, 2.17; 95\% CI, 1.17-4.05), or if they presented with anuria (HR, 5.24; 95\% CI, 2.29-12.03), coma (HR, 2.95; 95\% CI, 1.26-6.91), or cardiovascular failure (HR, 2.43; 95\%CI, 1.14-5.17) at admission [2]. Misset et al. have conducted a questionnaire survey and a multivariate analysis, wherein the occurrence of heatstroke at home or in a healthcare facility (vs. in a public area), high Simplified Acute Physiology Score (SAPS) II score

Table 2 Prognostic factors

\begin{tabular}{|c|c|c|c|c|c|}
\hline Study & Country & Patients & $\begin{array}{l}\text { Number of } \\
\text { patients }\end{array}$ & Outcomes & Factors \\
\hline $\begin{array}{l}\text { Hausfater et al. } \\
\text { [34] }\end{array}$ & France & $\begin{array}{l}\text { Nonexertional } \\
\text { heatstroke } \\
\text { (core body } \\
\text { temperature }>38.5^{\circ} \mathrm{C} \text { ) }\end{array}$ & 1456 & 1-year mortality & $\begin{array}{l}\text { Previous treatment with diuretics, } \\
\text { living in an institution, age }>80 \text { years, } \\
\text { presence of cardiac disease or cancer, } \\
\text { core body temperature }>40{ }^{\circ} \mathrm{C} \text {, SBP } \\
<100 \mathrm{mmHg} \text {, GCS score }<12 \text {, and } \\
\text { transportation to hospital in ambulance }\end{array}$ \\
\hline Argaud et al. [2] & France & $\begin{array}{l}\text { Nonexertional } \\
\text { heatstroke } \\
\text { (core body } \\
\text { temperature }>40^{\circ} \mathrm{C} \text { ) }\end{array}$ & 83 & 2-year mortality & $\begin{array}{l}\text { Living at an institution, the use of } \\
\text { long-term antihypertensive medication, } \\
\text { presence of anuria, coma, or } \\
\text { cardiovascular failure at admission }\end{array}$ \\
\hline Misset et al. [15] & France & $\begin{array}{l}\text { Heat stroke in } \\
\text { Bouchama's definition }\end{array}$ & 345 & Hospital death & $\begin{array}{l}\text { At home or in a healthcare facility } \\
\text { (vs. in a public location), high SAPS } \\
\text { II score, initial high body temperature, } \\
\text { prolonged prothrombin time and the } \\
\text { use of vasoactive drugs within the } \\
\text { first day in ICU, and patient management } \\
\text { in an ICU without air conditioning }\end{array}$ \\
\hline Tsuruta et al. [16] & Japan & $\begin{array}{l}\text { Mechanically ventilated } \\
\text { heat-related illness } \\
\text { in JAAM-HS criteria }\end{array}$ & 77 & $\begin{array}{l}\text { Poor outcome } \\
\text { (death and } \\
\text { incidence of sequelae) }\end{array}$ & $\begin{array}{l}\mathrm{SBP}, \mathrm{SpO} 2 \text { at scene, and } \\
\text { arterial base excess }\end{array}$ \\
\hline Hifumi et al. [22] & Japan & $\begin{array}{l}\text { Heat stroke in JAAM-HS-WG } \\
\text { criteria }\end{array}$ & 705 & Hospital death & $\begin{array}{l}\text { SBP, GCS score, serum } \\
\text { creatinine levels, and } \\
\text { presence of DIC }\end{array}$ \\
\hline
\end{tabular}


[35], initial high body temperature, prolonged prothrombin time, the use of vasoactive drugs within the first day in intensive care unit (ICU), and patient management in an ICU without air conditioning were independently associated with an increased risk of hospital death [15].

Tsuruta et al. have examined 77 mechanically ventilated patients with heat-related illnesses who met the JAAM-HS criteria. Their systolic blood pressure (SBP) and $\mathrm{SpO} 2$ at scene and arterial base excess were identified as independent risk factors for poor outcomes (death and with sequelae).

Hifumi et al. have examined 705 patients who met the JAAM-HS-WG criteria for heat stroke and observed that the hospital mortality was $7.1 \%$ (50 patients) [22]. Multiple regression analysis revealed that hospital mortality was significantly associated with SBP (odds ratio (OR), 0.99; 95\% CI, 0.98-0.99; $p=0.026$ ), GCS score (OR, 0.77; 95\% CI, 0.69-0.86; $p<0.01$ ), serum creatinine levels (OR, 1.28; 95\% CI, 1.02-1.61; $p=0.032$ ), and the presence of DIC on admission (OR, 2.16; 95\% CI, 1.094.27; $p=0.028$ ) [22].

According to the detailed analysis of risk factors, careful attention should be paid for the prevention of heat stroke in patients living in a healthcare facility, aged > 80 years, and previously treated with diuretics. Moreover, because hematological, cardiovascular, neurological, and renal dysfunctions on admission are associated with high mortality, these dysfunctions represent potential targets for intensive and specific therapies for patients with heat stroke.

\section{Treatment}

Heat stroke progresses to multiorgan dysfunction syndrome; therefore, rapid, effective cooling followed by close monitoring and specific treatment for injured organs are fundamental to treatment success.

\section{Initial cooling \\ Target temperature of initial cooling}

There is no evidence to support a specific temperature end point; however, a rectal temperature of $39.4{ }^{\circ} \mathrm{C}$ has been used in large series and has been proven to be safe [6].

\section{Initial cooling method}

To date, several cooling methods are available in the clinical settings, including immersion [36], evaporation [37], and the use of cold water bladders, gastric and rectal lavage [38], and noninvasive cooling systems [39]. However, there is no evidence supporting the superiority of any one cooling method for patients with heat stroke [6]. An intravascular balloon catheter system has been approved in the USA for therapeutic core cooling and rewarming in humans during or following cardiac or neurological surgery and following stroke [40]. However, a few cases have reported the use of intravascular cooling for heat stroke $[41,42]$. Hamaya et al. have reported for the first time a good recovery in a case of severe heat stroke, followed by multiple organ dysfunction, which was successfully treated through initial intravascular cooling [12]. In this case, at an average rate of $0.1{ }^{\circ} \mathrm{C} /$ $\mathrm{min}$, the core temperature of the patient's body reached $38.8^{\circ} \mathrm{C}$ after just $17 \mathrm{~min}$. Yokobori et al. have conducted a prospective study examining the feasibility and safety of a convection-based intravascular cooling device (IVC) in patients with severe heat stroke. Comparison between IVC plus conventional cooling (CC) and CC was made in patients with severe heat stroke. The IVC group showed a significant decrease in the Sequential Organ Failure Assessment score during the first 24 h (from 5.0 to $2.0, P=0.02)$. Moreover, all patients in the IVC group $(N=9)$ experienced favorable outcomes defined as modified Rankin scale score of $0-2$ at discharge and at 30 days after the admission. Their findings indicate that accurate temperature management may prevent organ failure and produce better neurological outcomes. The Fukuoka University Hospital group has used extracorporeal circulation with hemodiafiltration circuits for cooling patients with severe heat stroke and has reported improved cooling efficiency [43]. To date, there have been no prospective, comparative studies confirming the superiority of the initial cooling method. Intravascular balloon catheter system does not result in cutaneous vasoconstriction as external cooling does, but it requires the placement of cooling balloon.

\section{Management for organ dysfunctions in ICU Central nervous system dysfunction}

Nakamura et al. have examined central nervous system sequelae of heat-related illnesses and have observed that 22 of 1441 cases (1.5\%) exhibited the central nervous system sequelae of heat-related illnesses. Heatstroke patients presenting with lower GCS scores and higher body temperatures at admission were more likely to experience central nervous system sequelae and required longer cooling times to achieve the target body temperature. Therefore, rapid cooling followed by neuromonitoring might be associated with the neurological sequelae of heat stroke.

Recently, Hachiya et al. have reported the usefulness of $\mathrm{CEEG}$ in patients with severe heat stroke complicated with multiorgan failure [13]. The patients developed a persistent disturbance of consciousness; therefore, cEEG monitoring was applied. cEEG monitoring confirmed triphasic waves, which indicated hepatic failure as the cause of the persistent disturbance of consciousness. The patient's condition improved following an artificial liver support therapy [13]. Thus, no prospective, comparable study has revealed the adequate 
neuromonitoring and the effect of temperature control on central nervous system.

\section{Coagulation disorder}

\section{Anticoagulation therapy}

a. Antithrombin: Pachlaner et al. have reported good recovery in a patient with near-fatal heat stroke treated with type III antithrombin (AT-III) [44]. On admission, although the patient's AT-III activity was 98\%, a treatment with AT-III concentrate was initiated within $24 \mathrm{~h}$ due to DIC, which was aimed toward achieving supranormal plasma concentrations. Plasma AT concentrations were maintained at > $120 \%$ by continuous intravenous supplementation [44]. Additionally, in a rat model of heat stroke, ATIII treatment decreased serum cytokines (IL-1 $\beta$, tumor necrosis factor- $\alpha$, and IL-6), and HMGB1 [45]. Thus, prospective studies will be needed to confirm the efficacy of AT-III supplementation in improving the clinical outcome of heat stroke.

b. Thrombomodulin (TM): Recombinant soluble thrombomodulin $\alpha$ (rTM), which is currently under phase III clinical trials for use in patients with severe sepsis, could also be a candidate for the treatment of heat stroke-induced DIC [46] because it serves as a negative feedback regulator of blood coagulation [47]. In basic research, rTM prevents heat stroke by inhibiting HMGB1 [48]. Sakurai et al. have reported (in Japanese) two cases of good recovery from heatstroke-induced DIC, which were successfully treated with TM administration [49]. Prospective studies will be needed to confirm the efficacy of rTM.

\section{Hepatic/renal dysfunction}

Blood purification therapy Blood purification therapy has not been discussed in the two previously reported review articles; however, good recovery cases have been reported in Japan [6, 7].

Ikeda et al. have reported three cases of survival following multiorgan failure secondary to heat stroke that was treated with blood purification therapy, including continuous venovenous hemofiltration and plasma exchange (PE) [8]. Blood purification therapy removes proinflammatory cytokines related to heat stroke [8]. Chen et al. have conducted a retrospective study including 33 patients with severe exertional heat stroke and have compared clinical effects of continuous renal replacement therapy (CRRT) and routine therapy in these patients. They reported significantly lower 30-day mortality in the CRRT group than in the control group $(15.2 \%$ vs.45.5\%, $p=0.029$ ) although initial APACHE II scores in both groups were similar [10].

Recently, Inoue et al. have reported a case of severe exertional heat stroke with multiple organ failure that was successfully treated with continuous plasma diafiltration (PDF) [11]. PDF is a blood purification therapy in which $\mathrm{PE}$ is performed using a selective membrane plasma separator while the dialysate flows outside the hollow fibers. This separator has a small pore size $(0.01 \mathrm{~mm})$ and a sieving coefficient of 0.3 for albumin, which can selectively remove low- or intermediate-molecular weight albumin-bound substances [50-52].

In the clinical practice, decisions to continue blood purification therapy are difficult because this therapy is time-consuming and costly. Yonemitsu et al. have published a case report and literature review of cases of heat stroke treated with blood purification therapy [53]. The review includes several survival cases treated more than three times with PE; therefore, withdraw therapy following only a few trials. No prospective, comparable study has confirmed the efficacy of blood purification in heat stroke.

\section{Cardiovascular dysfunction}

Hart et al. have observed that supplementary vasoactive agents necessary to elevate blood pressure were associated with both high mortality rates and neurologic disability in patients with heat stroke [54]. Misset et al. have demonstrated that the use of vasoactive drugs within the first $24 \mathrm{~h}$ of admission to ICU was an independent factor associated with mortality. These findings suggest a close association between hypotension and poor outcomes. To date, no prospective, comparable study has confirmed the efficacy of targeted fluid administration or specific vasoactive drugs in heat stroke.

\section{Prevention}

It would be acceptable to consider prevention, rather than the treatment of organ dysfunctions, because therapeutic options for organ dysfunction are rather limited even in the late 2010s, as described above. Nonetheless, heat-related deaths and illnesses are preventable $[6,55]$. Heat stroke prevention strategies, such as using air conditioner; limiting outdoor activities during the daytime; consuming ample fluids; wearing loose-fitting light-colored clothing, being aware of medication side effects that may cause fluid losses, decrease sweating, or decreased heart rate; and never leaving impaired adults or children in a car unattended, are important [55]. Centers for Disease Control and Prevention has uploaded a video titled "How to Stay Cool in Extreme Heat" to YouTube [56]. 


\section{Conclusions}

In the present review, we elucidated the clinical diagnosis of heat stroke. Regarding the definition/classification of heat stroke, the Bouchama's definition and the JAAM criteria are the two available systems. Intravascular cooling devises provided rapid cooling in the small number of heat stroke patients. Although few case reports and retrospective case-series for the use of anticoagulation and blood purification therapies have been reported, particularly in Japan, no prospective, comparative study has been conducted to date. Further large studies are warranted to evaluate these treatment strategies among patients with heat stroke.

\section{Abbreviations \\ AKI: Acute Kidney Injury; ARDS: Acute Respiratory Distress Syndrome; CC: Conventional cooling; cEEG: Continuous Electroencephalogram; CRRT: Continuous Renal Replacement Therapy; DIC: Disseminated Intravascular Coagulation; GCS: Glasgow Coma Scale; HMGB1: High-mobility group box 1; HSP: Heat shock proteins; ICU: Intensive care unit; IVC: Convection-based intravascular cooling device; JAAM: Japanese Association for Acute Medicine; JAAM-HS-WG: Japanese Association of Acute Medicine heat stroke committee working group; JCS: Japan Coma Scale; PDF: Plasma diafiltration; PE: Plasma exchange; SAPS II: Simplified Acute Physiology Score II score; SBP: Systolic blood pressure}

\section{Authors' contributions}

TH wrote the manuscript. YK, KS, and YM revised and edited the manuscript. All authors read and approved the final manuscript.

\section{Ethics approval and consent to participate}

Not applicable

\section{Competing interests}

The authors declare that they have no competing interests.

\section{Publisher's Note}

Springer Nature remains neutral with regard to jurisdictional claims in published maps and institutional affiliations.

\section{Author details}

${ }^{1}$ Emergency Medical Center, Kagawa University Hospital, 1750-1 Ikenobe, Miki, Kita, Kagawa 761-0793, Japan. ²Department of Emergency and Critical Care Medicine, Juntendo University, Urayasu Hospital, 2-1-1

Tomioka,Urayasu-shi, Chiba 279-0021, Japan. ${ }^{3}$ Emergency and Critical Care Center, Tokyo Metropolitan Tama Medical Centre, 2-8-29 Musashidai, Fuchu-shi, Tokyo 183-8524, Japan. ${ }^{4}$ Department of Emergency Medicine, Teikyo University School of Medicine, 2-11-1 Kaga, Itabashi-Ku, Tokyo 173-8606, Japan. ${ }^{5}$ Department of Emergency and Critical Care Medicine, St. Luke's International Hospital, 9-1 Akashi-cho, Chuo-ku, Tokyo 104-8560, Japan

Received: 8 January 2018 Accepted: 8 May 2018

Published online: 22 May 2018

\section{References}

1. Gaudio FG, Grissom CK. Cooling methods in heat stroke. J Emerg Med. 2016;50:607-16

2. Argaud L, Ferry T, Le QH, Marfisi A, Ciorba D, Achache P, Ducluzeau R, Robert D. Short- and long-term outcomes of heatstroke following the 2003 heat wave in Lyon, France. Arch Intern Med. 2007;167:2177-83.

3. Dematte JE, O'Mara K, Buescher J, Whitney CG, Forsythe S, McNamee T, Adiga RB, Ndukwu IM. Near-fatal heat stroke during the 1995 heat wave in Chicago. Ann Intern Med. 1998;129:173-81.

4. Naughton MP, Henderson A, Mirabelli MC, Kaiser R, Wilhelm JL, Kieszak SM, Rubin CH, McGeehin MA. Heat-related mortality during a 1999 heat wave in Chicago. Am J Prev Med. 2002;22:221-7.
5. Semenza JC, Rubin CH, Falter KH, Selanikio JD, Flanders WD, Howe HL, Wilhelm JL. Heat-related deaths during the July 1995 heat wave in Chicago. N Engl J Med. 1996;335:84-90.

6. Bouchama A, Knochel JP. Heat stroke. N Engl J Med. 2002;346:1978-88.

7. Grogan H, Hopkins PM. Heat stroke: implications for critical care and anaesthesia. Br J Anaesth. 2002:88:700-7.

8. Ikeda Y, Sakemi T, Nishihara G, Nakamura M, Fujisaki T, Koh T, Tomiyoshi Y, Emura S, Taki K. Efficacy of blood purification therapy for heat stroke presenting rapid progress of multiple organ dysfunction syndrome: a comparison of five cases. Intensive Care Med. 1999;25:315-8.

9. Zhou F, Song Q, Peng Z, Pan L, Kang H, Tang S, Yue H, Liu H, Xie F. Effects of continuous venous-venous hemofiltration on heat stroke patients: a retrospective study. J Trauma. 2011;71:1562-8.

10. Chen GM, Chen YH, Zhang W, Yu Y, Chen JH, Chen J. Therapy of severe heatshock in combination with multiple organ dysfunction with continuous renal replacement therapy: a clinical study. Medicine (Baltimore). 2015;94:e1212.

11. Inoue N, Sato A, Ikawa Y, Shimizu M, Okajima M, Taniguchi T, Yachie A. Successful treatment of exertional heat stroke using continuous plasma diafiltration. J Clin Apher. 2016;31:490-2.

12. Hamaya H, Hifumi T, Kawakita K, Okazaki T, Kiridume K, Shinohara N, Abe Y, Takano K, Hagiike M, Kuroda Y. Successful management of heat stroke associated with multiple-organ dysfunction by active intravascular cooling. Am J Emerg Med. 2015:33:124. e125-7

13. Hachiya S, Okajima M, Nakamura M, Sato K, Koshida Y, Noda T, Taniguchi T. Usefulness of continuous electroencephalography in severe heat stroke complicated with multi-organ failure: a case report. J Japanese Assoc Acute Med. 2016;27:125-9.

14. Pease S, Bouadma L, Kermarrec N, Schortgen F, Regnier B, Wolff M. Early organ dysfunction course, cooling time and outcome in classic heatstroke. Intensive Care Med. 2009:35:1454-8.

15. Misset B, De Jonghe B, Bastuji-Garin S, Gattolliat O, Boughrara E, Annane D, Hausfater P, Garrouste-Orgeas M, Carlet J. Mortality of patients with heatstroke admitted to intensive care units during the 2003 heat wave in France: a national multiple-center risk-factor study. Crit Care Med. 2006;34: 1087-92.

16. Tsuruta $\mathrm{R}$, Aruga $\mathrm{T}$, Inoue $\mathrm{K}$, Okudera H, Kitahara $\mathrm{T}$, Shimazaki S. Predictors of poor outcome in mechanically ventilated patients due to heat-related illness. J Japanese Assoc Acute Med. 2010:21:786-91.

17. Nakamura S, Miyake Y, Dohi K, Fukuda K, Tanaka K, Aruga T. Sequelae in the central nervous system secondary to heat-related illness: an analysis of the heatstroke STUDY 2006 and heatstroke STUDY 2008. J Japanese Assoc Acute Med. 2011;22:312-8.

18. Final report of heatstroke study Japanese Association for Acute Medicine. 2014:25:846-62.

19. Ohta T, Kikuchi H, Hashi K, Kudo Y. Nizofenone administration in the acute stage following subarachnoid hemorrhage. Results of a multi-center controlled double-blind clinical study. J Neurosurg. 1986;64:420-6.

20. Gando S, Saitoh D, Ogura H, Mayumi T, Koseki K, Ikeda T, Ishikura H, Iba T, Ueyama M, Eguchi Y, Otomo Y, Okamoto K, Kushimoto S, Endo S, Shimazaki S. Disseminated intravascular coagulation (DIC) diagnosed based on the Japanese Association for Acute Medicine criteria is a dependent continuum to overt DIC in patients with sepsis. Thromb Res. 2009;23:715-8.

21. Singh RK, Baronia AK, Sahoo JN, Sharma S, Naval R, Pandey CM, Poddar B, Azim A, Gurjar M. Prospective comparison of new Japanese Association for Acute Medicine (JAAM) DIC and International Society of Thrombosis and Hemostasis (ISTH) DIC score in critically ill septic patients. Thromb Res. 2012; 129:e119-25.

22. Hifumi T, Kondo Y, Shimazaki J, Oda Y, Shiraishi S, Wakasugi M, Kanda J, Moriya T, Yagi M, Ono M, Kawahara T, Tonouchi M, Yokota H, Miyake Y, Shimizu K. Prognostic significance of disseminated intravascular coagulation in patients with heat stroke in a nationwide registry. J Crit Care. 2017:44:306-11.

23. Kushimoto S, Yamanouchi S, Endo T, Sato T, Nomura R, Fujita M, Kudo D, Omura T, Miyagawa N, Sato T. Body temperature abnormalities in nonneurological critically ill patients: a review of the literature. J Intensive Care. 2014;2:14

24. Hughes WT, Armstrong D, Bodey GP, Bow EJ, Brown AE, Calandra T, Feld R, Pizzo PA, Rolston KV, Shenep JL, Young LS. 2002 guidelines for the use of antimicrobial agents in neutropenic patients with cancer. Clin Infect Dis. 2002;34:730-51

25. Miyake Y. Pathophysiology of heat illness: thermoregulation, risk factors, and indicators of aggravation. Japan Med Assoc J. 2013;56:167-73. 
26. Rowell LB. Cardiovascular aspects of human thermoregulation. Circ Res. 1983;52:367-9.

27. Buono MJ, Sjoholm NT. Effect of physical training on peripheral sweat production. J Appl Physiol (1985). 1988;65:811-4.

28. Shimazaki. Pathogenesis of heat stroke. 2nd ed. Tokyo: Health; 2017.

29. Deschamps A, Levy RD, Cosio MG, Marliss EB, Magder S. Effect of saline infusion on body temperature and endurance during heavy exercise. J Appl Physiol (1985). 1989;66:2799-804

30. Tsai YC, Lam KK, Peng YJ, Lee YM, Yang CY, Tsai YJ, Yen MH, Cheng PY. Heat shock protein 70 and AMP-activated protein kinase contribute to $17-$ DMAG-dependent protection against heat stroke. J Cell Mol Med. 2016;20: 1889-97.

31. Lim CL, Mackinnon LT. The roles of exercise-induced immune system disturbances in the pathology of heat stroke: the dual pathway model of heat stroke. Sports Med. 2006;36:39-64.

32. Huisse MG, Pease S, Hurtado-Nedelec M, Arnaud B, Malaquin C, Wolff M, Gougerot-Pocidalo MA, Kermarrec N, Bezeaud A, Guillin MC, Paoletti X Chollet-Martin S. Leukocyte activation: the link between inflammation and coagulation during heatstroke. A study of patients during the 2003 heat wave in Paris. Crit Care Med. 2008;36:2288-95.

33. Tong HS, Tang YQ, Chen Y, Qiu JM, Wen Q, Su L. Early elevated HMGB1 level predicting the outcome in exertional heatstroke. J Trauma. 2011;71:808-14.

34. Hausfater P, Megarbane B, Dautheville S, Patzak A, Andronikof M, Santin A, Andre S, Korchia L, Terbaoui N, Kierzek G, Doumenc B, Leroy C, Riou B. Prognostic factors in non-exertional heatstroke. Intensive Care Med. 2010;36: 272-80.

35. Le Gall JR, Lemeshow S, Saulnier F. A new Simplified Acute Physiology Score (SAPS II) based on a European/North American multicenter study. JAMA. 1993:270:2957-63.

36. Weiner JS, Khogali MA. Physiological body-cooling unit for treatment of heat. stroke Lancet. 1980;1:507-9.

37. Al-Aska AK, Abu-Aisha H, Yaqub B, Al-Harthi SS, Sallam A. Simplified cooling bed for heatstroke. Lancet. 1987;1:381.

38. White JD, Riccobene E, Nucci R, Johnson C, Butterfield AB, Kamath R. Evaporation versus iced gastric lavage treatment of heatstroke: comparative efficacy in a canine model. Crit Care Med. 1987;15:748-50.

39. Hong JY, Lai YC, Chang CY, Chang SC, Tang GJ. Successful treatment of severe heatstroke with therapeutic hypothermia by a noninvasive external cooling system. Ann Emerg Med. 2012;59:491-3.

40. Diringer MN. Treatment of fever in the neurologic intensive care unit with a catheter-based heat exchange system. Crit Care Med. 2004;32:559-64.

41. Broessner $G$, Beer R, Franz G, Lackner P, Engelhardt K, Brenneis C, Pfausler B, Schmutzhard E. Case report: severe heat stroke with multiple organ dysfunction—a novel intravascular treatment approach. Crit Care. 2005;9:R498-501.

42. Megarbane B, Resiere D, Delahaye A, Baud FJ. Endovascular hypothermia for heat stroke: a case report. Intensive Care Med. 2004;30:170.

43. Murai A, Nakamura Y, Ichiki R, Yuge R, Umemura T, Ishikura H. Core temperature cooling of severe heat stroke patients using extracorporeal circulation with circuits of hemodialtration. J Japanese Assoc Acute Med. 2013;24:977-83.

44. Pechlaner C, Kaneider NC, Djanani A, Sandhofer A, Schratzberger P, Patsch JR. Antithrombin and near-fatal exertional heat stroke. Acta Med Austriaca. 2002;29:107-11

45. Hagiwara S, Iwasaka H, Shingu C, Matsumoto S, Uchida T, Noguchi T. Highdose antithrombin III prevents heat stroke by attenuating systemic inflammation in rats. Inflamm Res. 2010;59:511-8.

46. Vincent JL, Ramesh MK, Ernest D, LaRosa SP, Pachl J, Aikawa N, Hoste E, Levy H, Hirman J, Levi M, Daga M, Kutsogiannis DJ, Crowther M, Bernard GR, Devriendt J, Puigserver JV, Blanzaco DU, Esmon CT, Parrillo JE, Guzzi L, Henderson SJ, Pothirat C, Mehta P, Fareed J, Talwar D, Tsuruta K, Gorelick KJ, Osawa Y, Kaul I. A randomized, double-blind, placebo-controlled, phase $2 \mathrm{~b}$ study to evaluate the safety and efficacy of recombinant human soluble thrombomodulin, ART-123, in patients with sepsis and suspected disseminated intravascular coagulation. Crit Care Med. 2013;41:2069-79.

47. Mohri M, Sugimoto E, Sata M, Asano T. The inhibitory effect of recombinant human soluble thrombomodulin on initiation and extension of coagulation-a comparison with other anticoagulants. Thromb Haemost. 1999;82:1687-93.

48. Hagiwara S, Iwasaka H, Goto K, Ochi Y, Mizunaga S, Saikawa T, Noguchi T. Recombinant thrombomodulin prevents heatstroke by inhibition of highmobility group box 1 protein in sera of rats. Shock. 2010;34:402-6.
49. Sakurai S, Kitada M, Hashimoto S, Harada M, Kimura F, Takahashi T. Two cases of heatstroke-induced disseminated intravascular coagulation treated successfully with thrombomodulin alfa. J Japanese Assoc Acute Med. 2013; 24:367-73.

50. Nakae H, Eguchi Y, Yoshioka T, Yoshimura N, Isono M. Plasma diafiltration therapy in patients with postoperative liver failure. Ther Apher Dial. 2011;15:406-10.

51. Nakae H, Eguchi Y, Saotome T, Yoshioka T, Yoshimura N, Kishi Y, Naka T, Furuya T. Multicenter study of plasma diafiltration in patients with acute liver failure. Ther Apher Dial. 2010;14:444-50.

52. Nakae H, Igarashi T, Tajimi K, Noguchi A, Takahashi I, Tsuchida S, Takahashi T, Asanuma YA. Case report of pediatric fulminant hepatitis treated with plasma diafiltration. Ther Apher Dial. 2008;12:329-32.

53. Yonemitsu K, Haku K, Maeno Y, Ohnishi M, Nishino M, Kinoshita Y, Sadamitsu D. Successful conservative management of fulminant hepatic failure following exertional heatstroke. J Japanese Assoc Acute Med. 2008; 19:440-4.

54. Hart GR, Anderson RJ, Crumpler CP, Shulkin A, Reed G, Knochel JP. Epidemic classical heat stroke: clinical characteristics and course of 28 patients. Medicine. 1982;61:189-97.

55. Peiris AN, Jaroudi S, Heat Stroke NR. JAMA. 2017:318:2503.

56. How to Stay Cool in Extreme Heat [https://www.cdc.gov/disasters/ extremeheat/how_to_stay_cool_video.html].

\section{Ready to submit your research? Choose BMC and benefit from:}

- fast, convenient online submission

- thorough peer review by experienced researchers in your field

- rapid publication on acceptance

- support for research data, including large and complex data types

- gold Open Access which fosters wider collaboration and increased citations

- maximum visibility for your research: over $100 \mathrm{M}$ website views per year

At BMC, research is always in progress.

Learn more biomedcentral.com/submissions 